\title{
Occupational Choice and Job Opportunities in Technology and Vocational Education: The Need for Informed Decision-Making by Students
}

\author{
Dr. Japo Oweikeye Morto Amasuomo \\ Department of Vocational/Industrial Education, Faculty of Education, \\ Niger Delta University, Wilberforce Island, Bayelsa State, Nigeria \\ japoamasuomo@gmail.com, +2348033415457
}

\section{Doi:10.5901/jesr.2014.v4n1p453}

\begin{abstract}
The study investigated the need for students of technology and vocational education to be adequately informed when making decision in occupational choice and job opportunities. The information required by students when making informed decision in occupational choice and job opportunities were self profile evaluation; information on available occupations and job opportunities; information on the recognizable risk in various occupations and job opportunities as well as socio-economic information. One hundred and twenty seven (127) NCE II (200 Level) students of Technical Education, Federal College of Education (Technical), Omoku, Nigeria constituted the study population. The study sample was sixty (60) students. The Arithmetic Mean was used to determine whether in the opinion of the students there was need for informed decision-making in occupational choice and job opportunity. The Median score was 2.50. The Chi-square $\left(X^{2}\right)$ statistical method was used to test whether there was a significant relationship between the opinion of the students on the need for informed decision -making, and occupational choice and job opportunity in technology and vocational education. The findings established that at probability level of 0.50 , there was a significant relationship between students' opinion on the need for informed decisionmaking and choice of occupation and job opportunities.
\end{abstract}

Keywords: Occupation, job, technology education, vocational education, self-profile evaluation

\section{Introduction}

Students at the completion of primary and secondary education are usually faced with the uncertainty of future occupational choice and job opportunities. Any occupation that is chosen at this period by the student shall either uplift him socially or shall bring frustration later in future if decisions taken are not based on proper information. Occupation is a state of being employed or engaged in some profession, craft, trade, business or calling (Kirkpatrick, 1983; and Hayward \& Sparkes, 1976) while job is any undertaken or employment with a view to profit; or a work done for a stated price or a work for which you receive regular payment (Kirkpatrick, 1983; Hayward \& Sparkes, 1976; and Hornby, 2004). In this regard occupational choice and job opportunity could be describe as choosing a profession or craft or trade or pursuit in which one expects reward in terms of being paid a stated price or making profit or receiving regular payments from such pursuit. From the forgoing, it is pertinent that every young person before choosing an occupation should be properly informed and that decisions taken on any occupation should be realistic with respect to his or her immediate future.

Occupational choice is a natural phenomenon that is common to all human beings. It is an urge or desire to choose a vocation, and it determines the individual's life style and influence in the society. And because of the complex and uncertain job opportunities in the country, some youth aspire to enter occupations that do not suit their interests, values, abilities, skills, talents and personality characteristics. Therefore, inappropriate choice of occupation may spell ruin for the individual and force the society to function below the level of maximum efficiency (Nwankwo and Ebiringa, 1996). Therefore, unplanned and unwilling decision for a career have been observed to be detrimental not only to the individual who made the choice but also to his employer as well as the work embarked upon, since it is less likely to yield maximum satisfaction (Denga, 1982) and that whenever people find themselves into any profession due to any reason devoid of 'personal will' or choice, the tendency is likely to be job dissatisfaction, result into poor performance and care free attitude in the job (Olaitan, 1987). 


\subsection{Occupations and job opportunities}

Young persons who are trained in technical, vocational and technology education, are capable of getting employment in small, medium and large industries/factories.

\subsubsection{Occupations and Job Opportunities in Vocational Education}

Vocational education is a generic term that embraces all experiences an individual needs to prepare for some useful occupations but it excludes the professions and is specifically applied to employment in trade and industry, agriculture, home making and business areas (Giachino \& Gallington, 1977). In this regard, the vocational education is a training carried out at a post secondary school level. Occupations associated with vocational education are vocational-agricultural training, vocational-home making training and vocational-business training. Vocational-agricultural training assists people to become proficient in farming. It also provides opportunities for persons who wish to acquire the necessary information and skills in operating and managing a farm and in helping those who are already established to improve their efficiency in farming operations. Vocational home-making training enables families to improve the quality of their family life through a more efficient development and use of human and material resources. It is designed to help the individual to live a more useful and satisfying personal, family and community life. It deals specifically with financial planning, management of time and energy, human relationships and mechanics of housekeeping and utilization of technological development in the home. Vocational business training is concerned with equipping both youth and adults with those skills and knowledge, which will enable them, enter into or advance themselves in certain phases of employment in business. In business education, job opportunities could be found in various business establishments such as retailing, wholesaling, manufacturing, storing, transporting, financing and risk bearing.

\subsubsection{Occupations and job opportunities in industrial-technical education}

Industrial-Technical education program is also a post secondary school level training intended to produce a classification of workers referred to as technicians. In general term, a technician is a person who falls between the skilled crafts man and the graduate engineer or scientist. The technician-training program involves substantial concentration in applied mathematics, physics and chemistry, a high degree of technical knowledge and technical theory and considerable laboratory and mechanical operation procedure. Industrial-technical educational training could be divided into industrial technical and engineering technology. Industrial technology is either a two years National Diploma (ND) programme offered in the polytechnics or three year post secondary school Nigerian Certificate in Education (NCE) programme in technical and vocational education; and it is structured to train industrial technicians for the industry.

Job opportunities found in industrial-technical education/training are in research development, design, production, maintenance, testing, sales and supervision (Giachino and Gallington, 1977). The industrial technician is more jobs oriented and needs more training in manipulation skills, but less training in mathematics and science. Industrial technical covers occupational areas such as automobile, electrical/electronics, chemical/metalwork, woodwork, drafting, metallurgy, refrigeration and air-conditioning, computer and others.

Engineering Technology is much broader in scope and depth than industrial technology and is usually two years post industrial technical education known as Higher National Diploma (HND) and the programme is also offered in the polytechnics. An industrial technologist is therefore a person whose chief interest and activities lie in the direction of testing and development; the application and operation of engineering and scientific nature, largely upon his own initiative and under the general supervision of a professional engineer or scientist and who supplements his work (Henninger, 1959). Engineering technology covers occupational areas such as mechanical engineering, civil engineering, electrical engineering, electronic engineering, metallurgy engineering etc.

\subsubsection{Occupational and job opportunities in technology and vocational education in universities}

It is post-secondary school training in the universities with occupations in engineering, environmental, science, agriculture, management and programmes in the department of Technology/Vocational Education. Occupational trainings offered in engineering is civil, mechanical, and electrical/electronics, agricultural, computer, marine etc. It is usually of five years duration in engineering programs and four years duration for management sciences, sciences and technology/vocational education. The training program is geared towards the production of skilled manpower for the 
industrial sector and performs semi-professional functions of an engineering nature largely upon his/her own initiative and under a general supervision of the professional engineer (Giachino and Gallington, 1997; and Okorie, 2001). They perform semi-professional functions because it will take a minimum of two years of post qualification practice for them to sit for their respective professional examinations to qualify as professionals.

The universities also offer training programmes at postgraduate levels. The duration of such programmes is one or two years for master's degree certificate and a minimum of three years for Ph. D programmes. Graduates of postgraduate training can find job opportunities in Polytechnics, Colleges of Education or Universities as teachers. They can also find job opportunities in industries and research institutes.

\subsection{Information required for informed decision-making in occupational choice and job opportunities}

Information dealing with selection of and preparation for an occupation is referred to as occupational information (Giachino and Gallington, 1997). It covers four areas namely self-profile evaluation; information on available occupation and job opportunities; information on the recognizable risks of future employment; and socio-economic information. This information when made available to the young person enables him/her take realistic decision on the occupational choice and job opportunities for the immediate future.

\subsubsection{Self-profile evaluation}

Self-profile evaluation provides a basis for analysis and evaluating the characteristics, preferences and capabilities of the person. Therefore, exploration and self assessment are essential to making career decision (Miller 1985:101), and selfprofile evaluation instrument can be very simple or quite comprehensive depending on what one wants to evaluate (Giachino and Gallington, 1977). However, self-profile evaluation as an instrument for informed decision-making on occupational choice is important because technological complexities of the world is ever increasing and there is a greater awareness of the need for people to be better prepared to cope with the economic and social demands of society. Therefore, if the individuals are to meet their responsibilities realistically, they had to evaluate themselves before plunging into any occupation that will help them achieve economic independence, personal fulfilment and a better understanding of their potentialities and capabilities. Some of the indices for measuring self-profile evaluation are selfinterest, attitudes and the ability to develop skills as well as a good understanding of the occupation, job opportunities and job advancement possibilities.

\subsubsection{Information on available occupations and job opportunities}

The next step to be taken after self-profile is getting information on occupations and job opportunities that are available. This shall afford the young person obtain a variety of means and information on the characteristics of the range of job opportunities available to them and how to gain access to these job opportunities. Awareness of an occupation and job opportunities must occur before an individual acquires any inclination or preferences to perform that role. Therefore, the young person need to become aware of the competence needed for entering a self-fulfilling vocation. In this vein, the degree to which a student become aware of the world of work, understands the requirements for involvement in various occupations, and realize their own capabilities and possibilities will influence their ability to make rational choices that lead most students to entry positions appropriate for them (Miller 1985). Information required for occupational choice and job opportunities are usually the type of jobs available, working conditions, and opportunities for job advancement, employer-employee relationships, types and location of the industries requiring the various jobs

\subsubsection{Information on recognizable risk in occupations and job opportunities}

When a young person had evaluated his self-profile, and has made up his mind on an occupational choice through career information, he should also recognize the risk of future employment. The information on risk of future employment enables the young person understands the causes of risk, and knows how to mitigate its effect on them personally. The mitigation may come in form of retraining in related occupation. Some of the recognizable risks are risk of future employment, job mobility, and career and job security. Risk of future employment occurs when the old occupations are subsumed in new occupations to meet the changing needs of the society. When this happens, a young person in the occupation being phased out stand a risk of future unemployment. Every person making a choice of occupation therefore 
need to be prepared for specific occupations but progress must be functional and provide the kind of training which people must have to meet with the technological demands of today. Presently local communities are becoming discontinued from the curriculum of occupational training especially when new occupations are introduced. However, to mitigate its effect on the young person is for him to go for re-training in a related occupation. For example, most schools do not train persons to become painters and decorators. These occupations are now subsumed into building trades. The young person can switch over to be trained in the building trade. Also from the on-set, the young person should be trained in occupations that have job clusters.

Job mobility is another recognizable risk in occupations and job opportunities. Career mobility could be either vertical or horizontal. Business and industry recognizes the need for education and training at each point when changes in job descriptions are assigned to individuals. Thus, for a young person to be mobile in his/her place of work vertically or horizontally (changes in assignment) requires training. For example, a services station attendant, after successful work experience, might enter a training program for auto-mechanics. Upon completing this training, he may serve as apprentice mechanics. Furthermore, he could enter into training at a higher level to prepare for diagnosis of automotive performance, or managerial positions in the field of selling and servicing automobiles and so on.

In addition, career and job security is also recognizable risk in occupations and job opportunities. There are some occupations and job opportunities that do not have job security. These types of occupations and job opportunities are mostly found in pipe fitting, welding, diving etc. Persons involved in these occupations are usually employed as contract staff. They are paid high wages but the jobs are temporary in nature. At the end of each contract, the employee is retrenched and then waits for another round of employment when the employer secures another contract for execution. To mitigate this, young person should be trained in occupations that have job clusters.

\subsubsection{Socio-economic information}

Socio-economic information helps the young person understand how industry functions in a world in which people live and work (Giachino and Gallington, 1977), and also the available benefits in terms of government schemes and entitlements. This is because, various industries that provide occupations and job opportunities for technology and vocational trainees have become complex. Therefore, it is pertinent for the young person to have a much greater knowledge of the socio-economic problems as the various industries also become more complex. The socio-economic aspect of occupational choice and job opportunities are: workmen's compensation when there is lay-off and knowledge of entitlements to benefits; social security, which requires knowledge of government and voluntary opportunities schemes; the role of trade unions in negotiating wage rates, hours of work, overtime payments, special allowances, piecework arrangement, holidays work allocation, redundancy procedures, and job security; and medical care involving provision of medical services and welfare benefits for employee's children, spouse, and elderly relatives (Grant and Smith, 1969). Others are unemployment insurance when there is lay-off due to accident at work and the nature of entitlement to benefits; federal and state legislation on wages and working hours, knowledge of required information on minimum wage and the number of man hours that is expected to be put in the work per day; knowledge of labour laws with regard to employer-employee relationship, casualization, probation, rights and privileges of employee; and the quantity and quality of production, cost involved and the amount of production output expected of the employee so that employees are not over worked. In addition, the quality of production required by the employer so that employees are not faulted unnecessarily and the expected unit cost per production.

From the foregoing, most young people lack or not be afforded the required information that shall guide them to make realistic decision with regard to occupational choice and job opportunities? It is in realization of this that, the study tries to find out whether there is need for informed decision-making in occupational choice and job opportunities.

Therefore, the study is expected to find answers the to the following research questions.

1. What are the students' opinions on the need for information on self-profile evaluation when making informed decision in occupational choice and job opportunities?

2. What are the students' opinions on the need for career information when making informed decision in occupational choice and job opportunities?

3. What are the students' opinions on the need for information on the recognizable risks for future employment when making informed decision in occupational choice and job opportunities?

4. What are the students' opinions on the need for socio-economic information when making informed decision in occupational choice and job opportunities?

Based on the research questions, the following null hypotheses were postulated as a guide. 
1. The opinion of the students will show no preference on any of the self-evaluation information when making informed-decision in occupational choice and job opportunities.

2. The opinion of the students will show no preference on any of the occupation information when makinginformed decision in occupational choice and job opportunities.

3. The opinion of the students will show no preference for the recognizable risks in future employment when making informed-decision in occupational choice and job opportunities.

4. The opinion of the students will show no preference for the socio-economic informationwhen making informeddecision in occupational choice and job opportunities.

\section{Method}

\subsection{Participants}

The study population was made up of one hundred and twenty seven (127) second year NCE Technical Education students of the Federal College of Education (Technical), Omoku, Nigeria during the 2010/2012 academic sessions. A sample of sixty (60) students was randomly selected from the population.

\subsection{Instrumentation}

The research instrument was the questionnaire with the question items structured in form of statements. The questionnaire is divided into four sections: $A, B, C$ and $D$. Section A contains six items on self-profile evaluation; section $B$, six items on occupation information; section $C$, three items on information on the recognizable risks in future employment; and section D, eight items on socio-economic information when making informed-decision in occupational choice and job opportunities. Each question item had four (4) response options of very important (VI), significantly important (SI), important (I) and not important (NI) and were rated (4), (3), (2) and (1) respectively using a four point scale.

\subsection{Data analysis}

In analyzing the data arithmetic means was used to answer the research questions while the Chi-square $\left(\mathrm{X}^{2}\right)$ statistics was used to test the hypotheses. The mean scores of the students' opinion were calculated and the median score was 2.50. Students' means response scores greater 2.50 indicate positive response while mean responses below the median score is a negative response. The hypotheses were tested at the probability level of $5 \%$.

\section{Results}

The results in Table 1 with regard to research question 1 indicated that students need information on self-profile evaluation when making informed decision in occupational choice and job opportunities as revealed in all the assessed variables, where the mean scores were more than the median score of 2.50 . The average mean scores of the six (6) assessed variables of 3.44 were also more than the median score of 2.50 .

Table 1: Need for self-profile evaluation

\begin{tabular}{|c|c|c|c|c|c|}
\hline Question items & $\mathrm{VI}$ & SI & \begin{tabular}{l|l}
1 & 1 \\
\end{tabular} & $\mathrm{NI}$ & $\mathrm{X}$ \\
\hline In choosing an occupation, the ability to: & & & & & \\
\hline 1. recognizes self-interest and attitude for the occupation is -- & 43 & 12 & 4 & 1 & 3.61 \\
\hline 2. develop occupational and intellectual skills for successful employment is --- & 44 & 13 & 2 & 1 & 3.66 \\
\hline 3. develop necessary attitudes that shall have an impression or responsibility in the community is --- & 31 & 23 & 4 & 1 & 3.36 \\
\hline 4. gather occupational information from peer groups, parents, teachers etc is ---------- & 28 & 24 & 7 & 1 & 3.31 \\
\hline 5. properly assess the capability of making personal decisions on occupational choice is ------ & 36 & 15 & 4 & 5 & 3.36 \\
\hline 6. have a clear understanding of occupational clusters, opportunities, and job advancement possibilities is -- & 32 & 23 & - & 5 & 3.37 \\
\hline \multicolumn{5}{|l|}{ Average mean score } & 3.44 \\
\hline
\end{tabular}

Total $\mathrm{N}=60$, Median $=2.50$

The results in Table 2 pertaining to research question 2 revealed that, in all the assessed variables, the mean scores 
were more than the median score of 2.50. In addition, the average mean score of 3.39 for the six (6) assessed variables were also more than the median score of 2.50. That is, it was the opinion of the students' that, there was need for career information when making informed decision in occupational choice and job opportunities.

Table 2: Need for occupational information

\begin{tabular}{|c|c|c|c|c|c|}
\hline Question Item & $\mathrm{VI}$ & SI & 1 & $\mathrm{NI}$ & $\mathrm{X}$ \\
\hline In making occupational choice, understanding: & & & & & \\
\hline 1. knowing the type of occupation that is available is ------- & 34 & 19 & 8 & - & 3.55 \\
\hline 2. working conditions and compensation available from various occupations is -------- & 34 & 19 & 6 & - & 3.46 \\
\hline 3 type of preparations required before securing a job is --- & 39 & 17 & 4 & - & 3.58 \\
\hline 4. opportunities that are available for advancement or upward mobility or promotion in the job is ------ & 25 & 25 & 7 & 3 & 3.20 \\
\hline 5. relationship between the employer and the employee is - & 22 & 29 & 5 & 4 & 3.15 \\
\hline 6. Type of industries that requires the various occupations and where they are located is -------- & 30 & 28 & - & 2 & 3.43 \\
\hline \multicolumn{5}{|l|}{ Average mean score } & 3.39 \\
\hline
\end{tabular}

Total $\mathrm{N}=60$, Median $=2.5$

The results in Table 3 in respect of research question 3 further revealed that, it was important for students to have information on recognizable risks in future employment when making informed decision in occupational choice and job opportunities. In all the assessed variables, the mean scores were more than the median score of 2.50 .

Table 3: Recognizable risks in future employment

\begin{tabular}{|c|c|c|c|c|c|}
\hline Question Item & $\mathrm{VI}$ & $\mathrm{SI}$ & I & $\mathrm{N}$ & $\mathrm{X}$ \\
\hline $\begin{array}{l}\text { In making occupational choice, understanding whether the occupation: } \\
\text { 1. has been phased-out or become unproductive leading unemployment is ------- }\end{array}$ & 33 & 15 & 7 & 5 & 3.26 \\
\hline 2. has job mobility and advancement is -------- & 20 & 31 & 5 & 4 & 3.18 \\
\hline 3. is such that depends on contract and prone to retrenchment at the end each contract is ----- & 17 & 25 & 10 & 8 & 2.85 \\
\hline Average mean score & & & & & 3.10 \\
\hline
\end{tabular}

Total $\mathrm{N}=60$, Median $=2.50$

In addition, the results in Table 4 with regard to research question 4 also showed that, it was important for students to have socio-economic information when making informed decision in occupational choice and job opportunities. This was indicated in all the assessed variables, where the mean scores were more than the median score of 2.50; and the average mean score of 3.12 was also more than the median score of 2.50 .

Table 4: Socio-Economic Information

\begin{tabular}{|c|c|c|c|c|c|}
\hline Question Item & $\mathrm{VI}$ & $\mathrm{SI}$ & I & $\mathrm{NI}$ & $X$ \\
\hline In making occupational choice consideration for: & & & & & \\
\hline 1. workmen compensation when there is lay-off and entitlement to benefit is ------- & 34 & 19 & 2 & 4 & 3.35 \\
\hline 2. social security that requires knowledge of government and voluntary opportunity schemes is -- & 27 & 24 & 12 & 7 & 3.26 \\
\hline 3. knowledge of role of trade unions is -- & 17 & 24 & 17 & 6 & 2.85 \\
\hline 4. whether labour laws are pro-workers is- & 21 & 16 & 3 & 4 & 2.86 \\
\hline 5. statutory legislation on wages and work hours is -------- & 24 & 29 & 13 & 4 & 3.22 \\
\hline 6. the quality and quantity of production and cost is ---- & 29 & 14 & 12 & 3 & 3.13 \\
\hline 7. availability of unemployment insurance is ----------- & 16 & 29 & 5 & 4 & 2.97 \\
\hline 8. provision of medical care for employee and family by the employer is ----------------- & 34 & 17 & & & 3.35 \\
\hline \multicolumn{5}{|l|}{ Average mean score } & 3.12 \\
\hline
\end{tabular}

Total $\mathrm{N}=60$, Median $=2.50$

In table 5, the calculated Chi-square $\left(X^{2}\right)$ value of 31.58 for hypothesis 1 was greater than the critical table value of 14.34 at probability level of 0.50 and degree of freedom of 15 . Hence, the null hypothesis was rejected. Therefore, the opinion of the students showed preference for all the self-evaluation information when making informed-decision in occupational choice and job opportunities. 
Table 5: Test for goodness of fit for self-profile evaluation

\begin{tabular}{|c|c|c|c|c|c|c|c|c|c|c|}
\hline \multirow{2}{*}{ Item } & \multicolumn{2}{|c|}{ VI } & \multicolumn{2}{|c|}{ SI } & \multicolumn{2}{|c|}{ I } & \multicolumn{2}{|c|}{ NI } & \multirow{2}{*}{$X^{2}$} \\
\cline { 2 - 12 } & Obs. & Exp & Obs. & Exp & Obs. & Exp & Obs. & Exp & & \\
\hline 1. & 43 & 35.66 & 12 & 18.33 & 4 & 3.5 & 1 & 2.33 & 60 & 4.53 \\
\hline 2. & 44 & 35.66 & 13 & 18.33 & 2 & 3.5 & 1 & 2.33 & 60 & 4.90 \\
\hline 3. & 31 & 35.66 & 23 & 18.33 & 4 & 3.5 & 1 & 2.33 & 60 & 2.63 \\
\hline 4. & 28 & 35.66 & 24 & 18.33 & 7 & 3.5 & 1 & 2.33 & 60 & 7.66 \\
\hline 5 & 36 & 36.66 & 15 & 18.33 & 4 & 3.5 & 5 & 2.33 & 60 & 3.74 \\
\hline 6 & 32 & 35.66 & 23 & 18.33 & - & 3.5 & 5 & 2.33 & 60 & 8.12 \\
\hline \multicolumn{3}{|c|}{214} & \multicolumn{3}{|c|}{110} & \multicolumn{3}{|c|}{21} & \multicolumn{3}{|c|}{14} & 360 & 31.58 \\
\hline
\end{tabular}

$P<0.50 ; d f=15 ;$ t-critical $=14.34$

Also, the opinion of the students with regard to hypothesis 2 showed preference for all the occupation information when making-informed decision in occupational choice and job opportunities; as indicated in Table 6. The calculated Chisquare $\left(X^{2}\right)$ value of 23.96 was greater than the critical table value of 14.34 at 0.5 probability level and 15 degree of freedom. Hence, the null hypothesis was rejected.

Table 6: Test for goodness of fit on occupational information

\begin{tabular}{|c|c|c|c|c|c|c|c|c|c|c|}
\hline \multirow{2}{*}{ Items } & \multicolumn{2}{|c|}{$\mathrm{Vl}$} & \multicolumn{2}{|c|}{$\mathrm{SI}$} & \multicolumn{2}{|c|}{1} & \multicolumn{2}{|c|}{$\mathrm{NI}$} & \multirow{2}{*}{ Total } & \multirow[t]{2}{*}{$x^{2}$} \\
\hline & Obs. & Exp & Obs. & $\operatorname{Exp}$ & Obs. & Exp & Obs. & Exp & & \\
\hline 1. & 35 & 31 & 19 & 22.50 & 8 & 5.33 & - & 1.50 & 60 & 5.23 \\
\hline 2. & 35 & 31 & 19 & 22.50 & 6 & 5.33 & - & 1.50 & 60 & 2.64 \\
\hline 3. & 39 & 31 & 17 & 22.50 & 4 & 5.33 & - & 1.50 & 60 & 5.24 \\
\hline 4. & 25 & 31 & 25 & 22.50 & 7 & 5.33 & 3 & 1.50 & 60 & 2.41 \\
\hline 5 & 22 & 31 & 29 & 22.50 & 5 & 5.33 & 4 & 1.50 & 60 & 5.62 \\
\hline 6 & 30 & 31 & 26 & 22.50 & 2 & 5.33 & 2 & 1.50 & 60 & 2.82 \\
\hline Total & & & & & & & & & 360 & 23.96 \\
\hline
\end{tabular}

$\mathrm{P}<0.50 ; \mathrm{df}=15 ; \mathrm{T}$-critical $=14.34$

Further, the results of test for hypothesis 3 in Table 7 revealed that, the calculated Chi-square $\left(X^{2}\right)$ value of 14.98 was greater than the critical table value of 5.34 at 0.50 probability level and 6 degree of freedom.

Table 7: Test for goodness of fit on recognizable risk in future employment

\begin{tabular}{|c|c|c|c|c|c|c|c|c|c|c|}
\hline \multirow[b]{2}{*}{ Items } & \multicolumn{2}{|c|}{$\mathrm{VI}$} & \multicolumn{2}{|c|}{$\mathrm{SI}$} & \multicolumn{2}{|c|}{ I } & \multicolumn{2}{|c|}{$\mathrm{NI}$} & \multirow[b]{2}{*}{ Total } & \multirow{2}{*}{$X^{2}$} \\
\hline & Obs. & Exp & Obs. & Exp & Obs. & Exp & Obs. & Exp & & \\
\hline 1. & 33 & 23.33 & 15 & 23.66 & 7 & 7.33 & 5 & 5.66 & 60 & 7.27 \\
\hline 2. & 20 & 23.33 & 31 & 23.66 & 5 & 7.33 & 4 & 5.66 & 60 & 3.98 \\
\hline 3. & 17 & 25.33 & 25 & 23.66 & 10 & 7.33 & 8 & 5.66 & 60 & 3.73 \\
\hline Total & & & & & & & & & 180 & 14.98 \\
\hline
\end{tabular}

$P<0.50 ; \mathrm{df}=6 ;$ t - critical $=5.34$

Therefore, the opinion of the students showed a statistically significant preference on the need for information on the recognizable risks in future employment when making an informed-decision in occupational choice and job opportunities. Hence, the null hypothesis is rejected.

The results of Chi-square $\left(X^{2}\right)$ test in respect of hypothesis 4 indicated that, the calculated value of 57.71 was greater than the critical table value of 20.34 at 0.5 probability levels and 21 degree of freedom. The inference was that, the opinion of the students showed a statistically significant preference on the need for socio-economic information before making an informed-decision in occupational choice and job opportunities. Hence, the null hypothesis is rejected.

Table 8: Test for goodness of fit on socio-economic information 


\begin{tabular}{|c|c|c|c|c|c|c|c|c|c|c|}
\hline \multirow{2}{*}{ Items } & \multicolumn{2}{|c|}{$\mathrm{VI}$} & \multicolumn{2}{|c|}{$\mathrm{SI}$} & \multicolumn{2}{|c|}{ I } & \multicolumn{2}{|c|}{$\mathrm{NI}$} & \multirow{2}{*}{ Total } & \multirow[t]{2}{*}{$x^{2}$} \\
\hline & Obs. & Exp & Obs. & Exp & Obs. & Exp & Obs. & Exp & & \\
\hline 1. & 35 & 25.37 & 19 & 21.5 & 2 & 7.62 & 4 & 4.25 & 60 & 8.10 \\
\hline 2. & 27 & 25.37 & 24 & 21.5 & 7 & 7.62 & 2 & 4.25 & 60 & 1.64 \\
\hline 3. & 17 & 25.37 & 24 & 21.5 & 12 & 7.62 & 7 & 4.25 & 60 & 7.35 \\
\hline 4. & 21 & 25.37 & 16 & 21.5 & 17 & 7.62 & 6 & 4.25 & 60 & 14.42 \\
\hline 5. & 24 & 25.37 & 29 & 21.5 & 3 & 7.62 & 4 & 4.25 & 60 & 5.50 \\
\hline 6. & 29 & 25.37 & 14 & 21.5 & 13 & 7.62 & 4 & 4.25 & 60 & 6.95 \\
\hline 7. & 16 & 25.37 & 29 & 21.5 & 12 & 7.62 & 3 & 4.25 & 60 & 8.96 \\
\hline 8. & 34 & 25.37 & 17 & 21.5 & 5 & 7.62 & 4 & 4.25 & 60 & 4.79 \\
\hline Total & & & & & & & & & 480 & 57.71 \\
\hline
\end{tabular}

$P<0.50 ; d f=21 ; t-c r i t i c a l=20.34$

\section{Discussion}

The findings revealed that, information on self-profile evaluation was very important in students' opinion when making an informed decision in occupational choice and job opportunities. This is because; self-profile evaluation creates an avenue for analyzing and evaluating the characteristics, preferences and capabilities of the person. In a complex and technologically advanced world, there is a greater awareness of the need for people to be better prepared to cope with the economic and social demands of the society. Experiences in this regard has shown that a lot of frustration and manpower wastage occur where people are either not sufficiently aware of their own capabilities or not able to utilize such abilities effectively within the context of the society in which they live (Ezeh, 2000). The consequence of wrong choice of career without self-evaluation has had adverse effect on one's physical health, adjustment and job satisfaction (Nwankwo \& Ebiringa, 1999).

Information on the type of occupation available and possible job opportunities in students' opinion was also very important when making an informed decision in occupational choice and job opportunities as revealed in the findings. It means that, a young person needs to be properly informed and become aware of the competences required for entering a self-fulfilling vocation. There is therefore the need for students to have adequate information on the type of occupation that is available since choice of career to a large extent is dependent on availability of job, (Gidado and Yalams 1994).

Furthermore, it was the opinion of the students that, a young man who wants to choose an occupation must also recognize the risks involved when finally employed at the completion of occupational training. The risks in terms of job mobility, job security and whether the occupation could be overtaken by advancement in technology were considered important. Therefore, the choice of subjects at school, the application of oneself, and the channelization of interests and abilities will be more purposeful and more rewarding if one is aware of one's own professional destination, and the opportunities that exists for the realization of personal ambition (Ezeh, 2000). In addition, being aware of an occupational role regardless of the time it is developed must occur before an individual acquires any inclination on preferences to perform a role. A child therefore needs to become aware of the competences needed for entering a self-fulfilling vocation (Miller, 1985).

The findings also revealed that, there was need in the opinion of the students that, adequate knowledge of the socio-economic problems such as information on workmen's compensation, social security, trade unionism, pension schemes, medical cares, unemployment insurance as well as knowledge of labour laws was considered very important in occupational choice and job opportunities. However, socio-economic information is given less attention with regard to occupational choice. It is therefore regrettable because the complexity of industry today requires all workers to have a much greater knowledge of socio-economic problems than at any previous time in history. Information on socio-economic problems helps a student understand how industry functions in a world in which people live and work (Giachino and Gallington, 1977).

\section{Conclusion}

Many young people make occupational choice without affording themselves adequate information on the various occupations and the job opportunities. It was the opinion of the students who are faced with occupational choice and job opportunities that, there is every need for a young person to be adequately informed before choosing any occupation. 


\section{References}

Denga, D. I. (1982). Educational and Vocational Guidance in Nigeria Secondary Schools. Jos: Savanna Press Ltd

Ezeh, P. S. E. (2000). Prospects of Vocational Guidance and Counselling in the Ne National Policy. Journal of Vocational and Adult Education. Dept. of Vocational and Adult Education, Nnamdi Azikwe University, Awka, Anambra State. 2 (2), 82-90.

Gidado, B. K and Yalams, S. M. (1994). Factors Influencing Career Choice among Professional and Non Professional Technical Teacher in Bauchi State. Studies in Technical Teacher Education. Omoku, Nigeria: Federal College of Education (Technical). 1(1), $104-111$.

Giachino, J. W. and Gallington, R. O. (1977). Course Construction in Industrial Arts, Vocational and Technical Education. Chicago: American Technical Society

Grant, J. V. \&Smith, G. (1969), Personnel Administration and Industrial Relations London: Longman, Green and Co. Ltd.

Hayward, A. L \& Sparkles, J. J. (1976). Cassell's English Dictionary. London: Cassell and Company

Hornby, A. S. (2006). Oxford advanced learner's dictionary (New $7^{\text {th }}$ Ed). Oxford: Oxford University Press.

Kirkpatrick, E. M. (1983). Chambers 20th Century Dictionary. Edinburgh: W.D. R Chambers Ltd

Miller, M. D. (1989). Principles and a Philosophy for Vocational Educational. Columbus Ohio: National Center for Research in Vocational Education

Nwankwo, O. C. \& Ebiringa, C. O. (1996). A Comparative Analysis of Motivation for Occupational Choice between Professionals and Students. Nigerian Journal of Professional Studies Professional Studies in Education. 4, 122 - 129.

Olaitian, S. O (1987). Correlates of Job Satisfaction of Academic Staff of Nigerian Universities: A case study of the University of Nigeria. International Conference on Teaching Practice and Teachers' Effectiveness held at University of Nigeria, Nsukka 
